\title{
Revisiting the Mesopotamian City: a Drawing of its Inhabitants' Mental- Image
}

\author{
Saba Sami Al Ali ${ }^{1}$
}

\section{Authors affiliations: \\ 1) Department of Architectural Engineering, Al Nahrain University of, Baghdad-Iraq. email@,website.com}

\section{Paper History:}

Received: $20^{\text {th }}$ April 2021

Revised: $18^{\text {th }}$ May 2021

Accepted: $13^{\text {th }}$ July 2021

\begin{abstract}
Mesopotamian cities were formed sometime during the fourth millennium BCE, and many of them continued to be inhabited as much as 3000 years. While urban characteristics of these cities has been extensively studied, the current article is concerned with exploring the inhabitants' daily experience in the city; a subject that has not been sufficiently explored despite its importance in urban studies. The objective is to expand the understanding of the relation between the ancient city and its occupants. The paper adopts the concept of the City Image as introduced in the seminal work of Kevin Lunch "Image of The City" in investigating aspects of the Mesopotamian city that qualifies it to form a strong mental Image for her citizens, derived from the legibility of its elements and the structure they form. Using a descriptive analytical method in reviewing previous literature, the research first clarifies the shared characters of Mesopotamian cities, and addresses the stature of the city in Mesopotamians' culture. I then specify the five urban elements of the city image as categorised by Lynch; paths, nodes, edges, districts and landmarks, in addition to addressing manifestations of the citizens' urban life in the Mesopotamian city. Afterward, visualization of the citizen's daily experience through the urban fabric of the city is provided, to arrive at a conclusion of the Legibility of the mental image of the Mesopotamian city in the perception of its citizens.
\end{abstract}

Key words: Mesopotamian City, Urban life, Image of the City, Mental Image, Inhabitants' Perception.

$$
\begin{aligned}
& \text { مراجعة المدينة الرافدينية : رسم الصورة الذهنية لدى سكانها }
\end{aligned}
$$

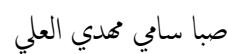

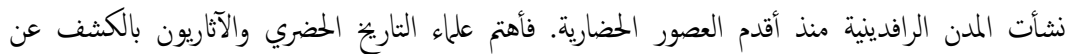

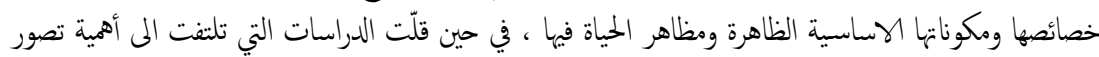

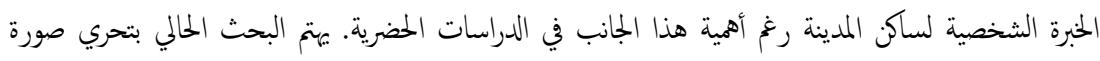

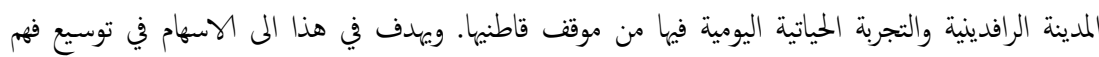

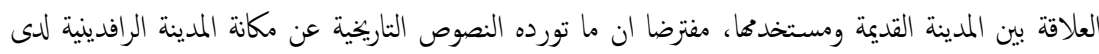

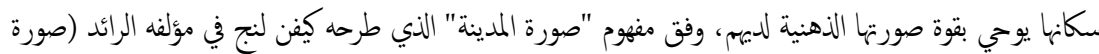

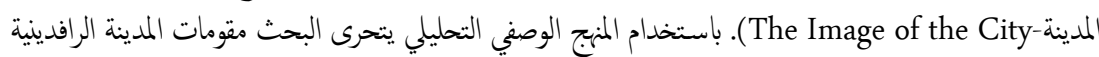

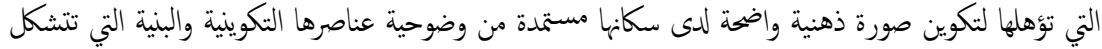

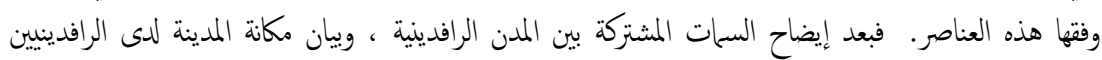

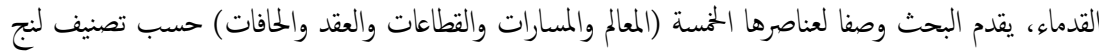

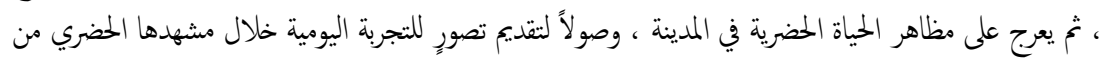

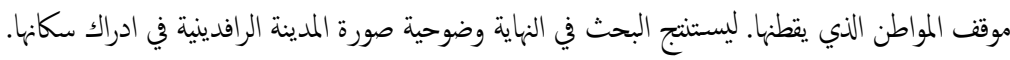

NJES is an open access Journal with ISSN 2521-9154 and eISSN 2521-9162

This work is licensed under a Creative Commons Attribution-NonCommercial 4.0 International License 


\section{Introduction}

The work of Lynch constitutes a seminal approach for urban studies which was followed by many scholars with variations and extensions in concepts. Its importance stems from the steering of studies to consider not just "the city as a thing in itself, but the city being perceived by its inhabitants". While his work targeted urban designers and planners of his time, the concept of the (Image of the City) which he introduced still represent an essential pillar in the analysis of urban dynamics, as shown in the study [1] where a computational approach to The Image of the City is proposed. Similarly, Lynch's work can be of relevant importance to historians of urbanism in trying to portray perceptions and daily experiences of the citizens' urban life in ancient cities. The objective of this article is to highlight this potential by looking at the example of Mesopotamian cities.

Mesopotamian cities had been a focal subject for scholars of history and archeology of urbanism, as Mesopotamia is the land where cities were first invented. However, most relevant comprehensive studies on the urban characteristics of Mesopotamian cities look at their apparent components and aspects of urban life; social, economic, political or religious, from an outsider standpoint, which is the view of the researcher as an examiner as in Stone's account in [2] and other studies, like those presented in Oxford's History of Urbanism of 2016, where a focus on each city's history and leading role in Mesopotamian civilization is explained. Few articles presented visions from the inhabitants' position. Such as the visitor's journey portrayed in few lines by Meiroop's (1999) study [3], or the article by Hafford (2018) which described in fewer lines the daily routine of the ancient Mesopotamian around 4,000 years ago [4]. While the study by McMahon [5] tried to show qualities of approaching spaces in the Khorsabad palace entrance from the view of a moving person, to prove that those spaces were designed to lead intentionally the visitor with total control on his senses. The present article attempts at extracting a larger scale experience of the Mesopotamian man in his supposed daily journey through the urban landscape of a typical Mesopotamian city. In this drawn journey, the presence of the five elements of the city is revealed, and thus illustrating the justification of the the city's legibility which qualifies its image- ability.

\section{Justifying the Model of a Mesopotamian City}

Mesopotamia covers all modern Iraq and the Northern east part of Syria, bounded by the Euphrates to its west. ${ }^{1}$ This geographical region has been differentiated by scholars ecologically and culturally into two zones: Lower and Upper Mesopotamia.

\footnotetext{
${ }^{1}$ It is quite safe to consider modern Iraq as Mesopotamia proper, nevertheless for easiness, only (Mesopotamia) will be used through the article.
}

Lower Mesopotamia is flat and dry but with alluvial plains and herding lands extending in southern Iraq where permanent settlements depended for irrigation on natural or artificial watercourses. It was known in early times as Sumer and Akkad, and after 2000 BCE as Babylonia.

Upper Mesopotamia, known in later times as Assyria is more varied in relief and received enough rainfall to enable dry farming and settlement through the countryside.

Babylonia and Assyria represented two different cultures in many aspects; yet they became intrinsically bound after $1500 \mathrm{BCE}$, and Assyria adopted many of Babylonia's traditions and the concept of the city itself may have been introduced to Assyria from the south. ${ }^{2}$ Accordingly, despite the differentiation between the two Mesopotamian regions which affected their settlements' types ${ }^{3}$, many shared urban characteristics that allow a generalized picture of the city are present. This will of generalization is in a sense an acknowledgement of the unity and coherence of Mesopotamian civilization.

\section{Shared Urban Traits of Mesopotamian Cities:}

By observing maps drawn for uncovered sites of different Mesopotamian cities, shared characteristics are clearly noticed. Most cities usually consist of three main zones: first, one or two centers comprising the religious and administrative institutions. Second, the surrounding area of residential neighborhoods and third the peripheral zone which includes the city wall and gates in addition to spaces left inside and the surrounding area outside.

Cities which gradually developed from older settlements appear with walls' shapes often nearly oval, due to the successive agglomeration of houses around its center. Uruk and Ur are examples. ${ }^{4}$ In such cities residential quarters appear in the shape of clusters of courtyard houses, one or two storey

\footnotetext{
2 Meiroope 1999, p8, although recent excavations at the site of Tell Brak and Tell Hamoukar in North east Syria has revealed the growth of urban- sized site, urbanized regional settlement hierarchies, monumental public buildings, and socio-economic complexity from as early as the late $5^{\text {th }}$ millennium BCE, or c.4200 BCE,(McMahon,p34) but these centers diminished right before the rise of proper urbanization of Uruk, and consequently most aspects of later Assyrian cities are bound to lower Mesopotamian cities traits rather than to those of North east Syria settlements.

${ }^{3}$ It is stressed by scholars that the knowledge concerning Mesopotamian cities is fragmented and interspersed with gaps.

${ }^{4}$ However, exceptions exist following topographical varieties and special preferences for the center location. The city of Assure in the North has its center directly at the highest bank of the Tigris, and the surrounding residential quarters followed the almost triangular shape layout to the south of it, while Nippur's walls define an almost rectangular shape
} 
flanking narrow meandering alleys. The wider alleys lead indirectly to the center and there are often some that penetrate, not directly, from the city gate to its center. ${ }^{5}$

On the other hand, cities which were erected due to rulers' decisions often take clear geometrical shapes rectangular or square. Examples are Assyrian imperial cities of the first millennium BCE like Dur Sharrukin and Kalhu. Although knowledge of the residential quarters in these Assyrian cities is weak, late Chaldean Babylon of the mid-1 ${ }^{\text {st }}$ millennium BCE draws a picture of the city's potential for representing control of space and place. Blocks of houses in Babylon were regulated geometrically with straight main roads, whether connecting city gates or leading to the center. However, courtyard houses remained cluster together, attached in a semi- organic typology filling the orthogonal regulating blocks [6]. Some scholars mention that houses in inner cities of upper Mesopotamia seem to be less numerous because settlement in villages throughout the well-watered plains of the countryside was possible.[3]

In both categories the center appears planned in geometrical layout, comprising large open courtyards, and often defined with straight inner walls. The peripheral zone, on the other hand has the outer defensive wall of the city as a middle boundary defining its shape and size. Spaces on both sides of the walls are believed to be active areas for city's inhabitants and visitors, as will be explained later.

Although exceptions do exist in features of both categories, the result, for the first category, is mostly an oval city, with organic urban fabric surrounding a well- defined geometrical center. For the second category, it is a rectangular or square city with semiorthogonal urban fabric surrounding a geometrical center. The interest here is to stress that despite this difference in general morphology, the inhabitant image of the city can be modeled on its shared elemental components and its salient aspects of the urban life of citizens.

\section{The City in Mesopotamians' Culture}

An ordered environment (...) may serve as a broad frame of reference, an organizer of activity or belief or knowledge. A good environmental image gives its possessor an important sense of emotional security. He can establish a harmonious relationship between himself and the outside world. [7]

It is not difficult to track the above mentioned emotional bond and the appreciation that Mesopotamians had for their cities, which might suggest how successful they found their urban environment beside recognising and enjoying its image by living in those cities. Although scholars note a lack of distinction in language in denoting the word city but this isn't by any means a sign of undifferentiation [8]. ${ }^{6}$ The concept of citizenship is

\footnotetext{
5 Residential quarters are not widely excavated by archeologists, they are time and effort consuming with less rewarding results compared to the institutional center of the city.

6 The terminology of Sumerian and Akkadian has no distinct word denoting the "City". The Sumerian
}

clearly manifested in different cuneiform inscriptions whether regarding the inhabitants' self-qualities or the city's stature.

Inhabitants of the city were well aware and proud of their distinct qualities as civilized cultured people unlike outsiders living around Mesopotamia. "A passage in a Sumerian poetic text written in praise of Ur asserts that even a native Marhsi- a mountain region of Elam- becomes civilized when living in Ur"[8] Civilized living for a Mesopotamian had specific traits including obedience to the proper authorities on the same level as worship for the gods, together with certain eating habits and burial costumes which separate the civilized from the uncivilized. [8]

"From the first millennium BCE there are Indications that a small number of old and important cities enjoyed certain privileges and exemptions with respect to the king and his power. In Babylonia these cities were Nippur, Babylon and Sippar; in Assyria, the old capital Assure and later Harran in Upper Mesopotamia. Also Inhabitants of these free cities claimed freedom from corvee work, freedom from military service, as well as tax exemption. These privileges were under divine protection. Their legal status was referred to as the kidinnūtu ("status of being under the aegis of the kidinnu" probably some kind of standard). Citizens of Babylon and other Mesopotamian cities appear thus to have become a class set apart from and above the rest of the population not for ethnical or economic reasons but solely because they were natives of certain cities." [8]

The emotional side of the citizen- city relationship can also be traced in Inscriptions. For Ancient Sumerians, the prosperity of the city reveals an effort if not undertaken by the powerful ruler, then by the deity guarding this city. "Sumerian Mythology reveals the efforts of tutelary deities of ancient cities to require the blessings of the God Enlil who resides in Nippur the center of religion to ensure prosperity of their cities, the journey of Nanna god of Ur to Nippure is an example" [9].

Another myth about Inanna the queen of Heaven and love, the tutelary goddess of Uruk (Erech), tells how she, through trickery, obtained from her father Enki the lord of wisdom who dwells in Eridu, the divine laws, the me's which govern mankind and his institutions, and brought them by boat to Uruk, to increase its prosperity and welfare and make it the center of Sumerian civilization. As explained by Kramer, the author of the myth gave a full list of the me's and divided civilization as he conceived it into over 100 hundred culture traits and complexes relating to man's political, religious and social institutions, to the arts and crafts, to music and musical instruments and to a varied assortment of

terms uru and alu both apply to every permanent settlement whether a city or village or even a complex of houses or huts. Only the term (é, uru. $\dot{s}=$ Kapru) is used for manors, and (é. durus, hașāru, etc) for rural settlements [8], [3] . It is also noticed that the representation of the city is very rare in Mesopotamian art. 
intellectual, emotional and social patterns of behavior [9]. ${ }^{7}$

The destruction of the city and its temple was revealed in Mesopotamian poetry as most disastrous and painful calamity for people. The (Lamentation over the destruction of Ur) paints a picture of "the utter desolation that befell Ur and its temple after the Elamites had attacked it and carried of Ibbi-Sin, the last ruler of the Third Dynasty of Ur in 2004 BCE"[10].

As shown above, Mesopotamian cities influenced their inhabitants' sentiments and framed their beliefs. Such influence must have been sustained by a strong mental image the residents and visitors had for those cities. In the following, the research will try to trace the urban elements which formed that image.

\section{Urban Image of the Mesopotamian City:}

In drawing the urban Image of Mesopotamian city two main interconnected aspects need to be brought together to reveal a comprehensive view, these are the urban elements of the image and aspects of urban life of the inhabitants.

\subsection{The Five elements of the City's Image}

The three zones of the Mesopotamian city described above comprise the five elements which were categorised by Lynch.; Landmarks, Paths, Sectors, edges and districts.

\subsubsection{Landmarks}

Landmarks are point references considered to be external to the observer. They are more easily identifiable, if they have a clear form; if they contrast with their background; and if there is some prominence of spatial location. [7]

In referring to this definition, the main landmarks of Mesopotamian city may be identified in the architecture of the Palace, Temples as well as Gateways of the city wall.

The institutional center is the religious, political and/or economic headquarter. Its main buildings are usually the main temple with its massive ziggurat which is the stepped temple tower, dedicated to the patron deity of the city, and the ruler's main palace. These are often surrounded by an inner wall, together, as in Ur and Dur Sharrukin (Khorsabad) or separately as in Late Babylon. Other religious or administrative buildings could be enclosed within the center, and the access to the whole complex was limited. ${ }^{8}$ The main temple was always in the highest

7 In [9], p116 see most of these me's mentioned by the myth author.

8 Polycentric cities appeared in Assirya and Babylonia as well. The city of Uruk is famous of its two oldest religious centers; the complex of Eanna precinct of $3200 \mathrm{BCE}$ and the Temple of Anu on its ziggurat of the late $3^{\text {rd }}$ Millenium BCE., while Khorsabad $8^{\text {th }}$ century BCE showed two administrative nuclei; the castle of Sargon II with the main temple and palaces and king's heir palace in the peripheral zone of the city. part of the city ${ }^{9}$, the palace usually was not raised like temples. However, the center complex served as a focal point and prominent landmark in the city with its monumental scale of architecture characterized by decorated buttressed walls and projected formal entrances.

City gates as well had distinctive architecture. They were higher than the attached walls projecting buttresses and towers. Their importance is also manifested in their given distinguishing names. See Figure 1

\subsubsection{Districts:}

Districts are the relatively large city areas which the observer can mentally go inside of, and which have some common character [7].

The institutional center forms a distinctive district in itself, as it is secluded within the inner walls. On the other hand, neighborhoods can easily be identified comprising multiple districts. They have common salient traits that depict their homogeneity. Neighborhoods were of courtyard houses attached mostly from three sides often leaving one façade to the street. Figure 2

Houses were constrained by each other in terms of space and property lines, without a consistent orientation. They were not strictly geometric, and their outlines and internal subdivisions changed gradually over time. Houses varied in size but they relatively were close proximity.

In addition to houses, neighborhoods included several shops, small shrines for relatively minor Mesopotamian deities and sometimes small workshops, spread within the irregular fabric, as revealed in Babylonian Ur.

Although no firm evidence confirms that each craft was concentrated in a specific neighborhood, A case in point is offered by references in late $\mathrm{NeO}$ Babylonian texts to the city" of the tanners and the city of the metalworkers. This is explained as referring to the special quarters to which certain crafts were either restricted or in which they were concentrated for mutual convenience [8]. These quarters might have been in distinctive districts too.

\footnotetext{
${ }^{9}$ In Assyria the site is originally chosen in an elevated point, while in Babylonia it became elevated due to the successive reconstruction of the main temple on the ruins of the previous deteriorated structure according to Mesopotamian culture.
} 


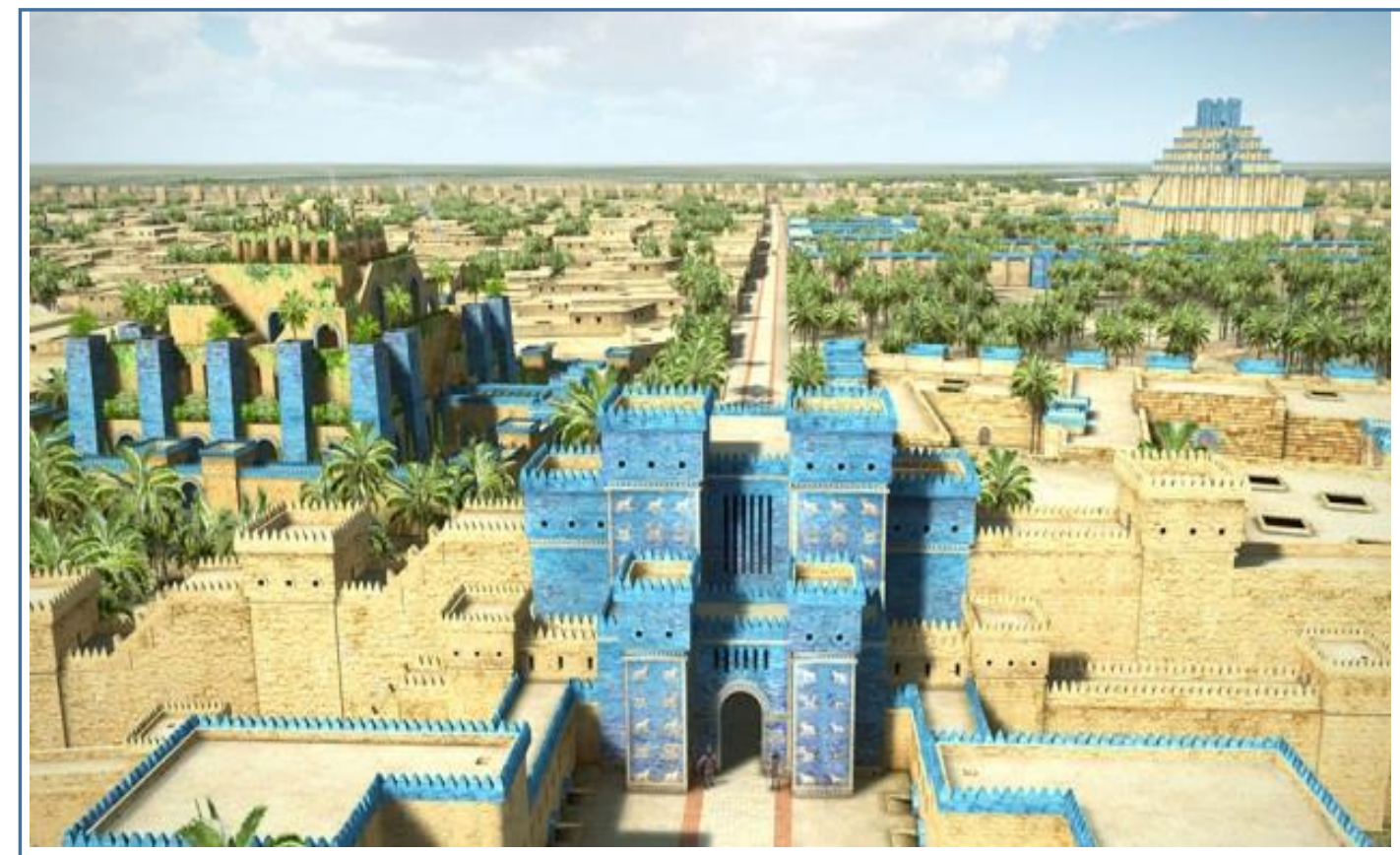

Figure 1: Babylon, Mid 1 ${ }^{\text {ST }}$ Century BCE. source : (website 3)

The Ishtar Gate, The Ziggurat and the Hanging Gardens, all are prominent landmarks of the city.

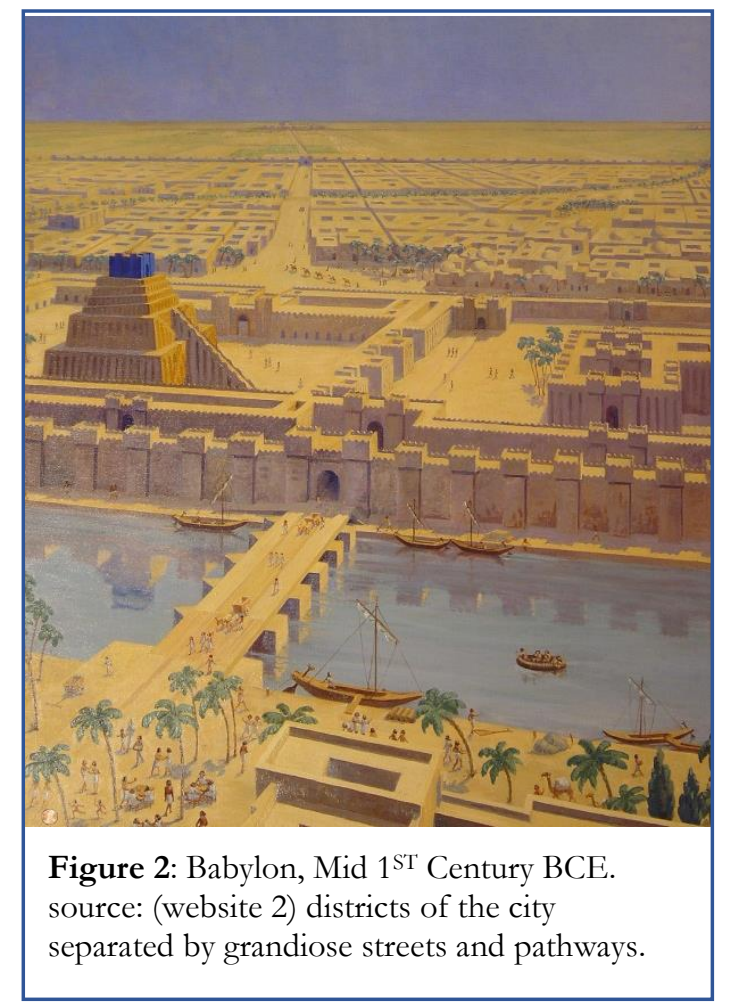

The harbor might also be a separate district outside the city wall where it might act as a neutral zone without direct supervision of the urban political power. According to textual resources, the harbor section, the Kar in Sumerian, Karu in Akkadian, had administrative independence and also separate legal status important for the citizens transacting business there. In the kāru lived the foreign traders; there they had their stores and were provided for by the tavern keeper of the kâru.[8]

\subsubsection{Paths:}

Paths are the channels along which the observer customarily, occasionally, or potentially moves. (..). People observe the city while moving through it, and along these paths the other environmental elements are arranged and related [7]

The main paths that citizens use in Mesopotamian cities are canals and streets that leaded to the main destinations an individual might need.

Canals running through the city were used for transport. In that they are significant paths that traverse the city. See Figure 3

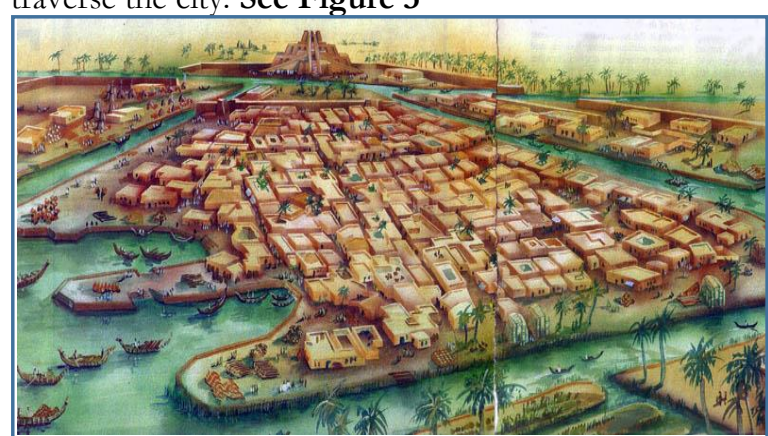

Figure 3: Imagined view of Mashkan Shapir: source: (website 3), illustrating canals as main paths

Cities also contained major thoroughfares. These were primal paths for entering the city or ceremonial activities in specific events. They had lustrous names like 'pray and he will hear you' in Babylon, or named after a god or an ethnicity group. More minor streets and alleyways existed also, sometimes named after the principal resident. Some cities' sites show that the main streets paralleled the main canal or running more or less at right angles to them [2],[3]. These streets vary in width and length according to the city 
size and density of its population and to what extent its administration authorities undertake maintenance. King Sennacherib states that he widened the market street of Nineveh enough to make it royal road, and made it shine (enlightened) like the day [11]. Nabukhadnazar II also paved the processional road of Babylon from out of city through the Ishtar Gate to the temple of Marduhk and adorned its flanking walls with glazed ceramics with reliefs. Minor roads, whether straight or not, were sometimes paved with stone or gravel.

Main streets are connected to the city districts by secondary paths, which then branch into narrower meandering alleys and paths through the residential areas.

\subsubsection{Nodes:}

Nodes are the strategic foci into which the observer can enter, and which are the intensive foci to and from which he is travelling. They may be primarily junctions, places of a break in transportation, a crossing or convergence of paths (...) or the nodes may be simply concentrations, which gain their importance from being the condensation of some use or physical character. [7]

There are few areas in the Mesopotamian city that fulfill the definition of the Node as a junction or as concentration. For the first type, nodes could be generated at the intersections of streets and alleys where small plazas are formed, thus constituting a welcoming place for public interaction. For the second, the market area could be considered a main public concentration focus. As Mesopotamian cities lack clear physical evidence of markets, it is thought that locus for vibrant commercial exchange are centered in areas such as the open edge zones which form the irregular area left between the end of houses' clusters and the wall of the city, in addition to the inside or outside areas near the gateways of the city, as well as near the city harbor. Similarly the city harbor could also be a prominent node if located inside the city, as mentioned previously. As for the internal courtyards in the precinct of temples, they could not attract condensation of public since their use was often restricted, unless certain religious ritual is performed and public are allowed to participate, then it acts as a node of concentration. See Figure 4.

\subsubsection{Edges:}

Edges are linear elements not considered as paths: they are usually, boundaries between two kinds of areas. They act as lateral references. Those edges seem strongest which are not only visually prominent, but also continuous in form and impenetrable to cross movement [7].

The outer wall of the city with areas on its both sides represents the main edge in the Mesopotamian city. The wall defined the boundaries of the city and with its fortifications protected it against greedy enemies. Walls also diverted flood water whenever the Tigris or the Euphrates burst their banks. The city walls were buttressed by towers or bastions higher than the wall itself. The wall of Uruk was found to be 9.5 kilometers long with nearly a thousand semicircular bastions and a surrounding moat completes the defense precautions. As mentioned above, massive buttressed gates gave access to the city.

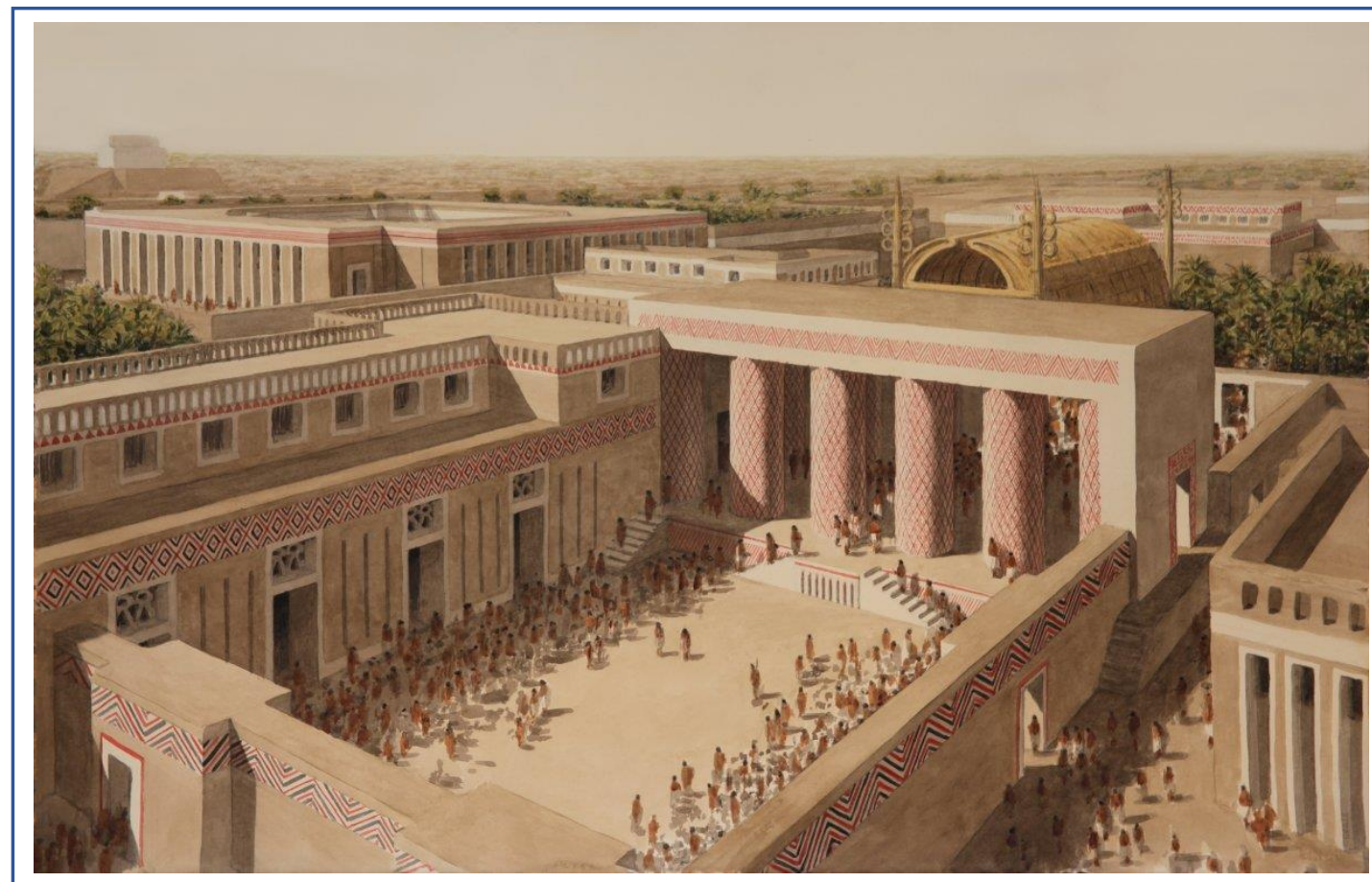

Figure 4: The Ceremonial Entrance to the Eanna Temple Complex, Uruk Period, 3200BC. Source: archeology illustrated.com (website 4). The photo illustrates the architecture of the temple institution hosting public rituals in the open courtyards thus acting as concentration nodes. 
Canals and water courses were indispensable elements inside or near the Mesopotamian city. Inside the city they form clear edges for districts. They served as a source of water for habitants, in addition to being major routes of communication and trade especially when extended out from the city. ${ }^{10}$ In some cities, in lower Mesopotamia like Mashkan- Shapir more than one canal can be found as in Figure 3 . Canals running through the city end up in harbors inside the city walls near the main gates. See Figure $\mathbf{5}$

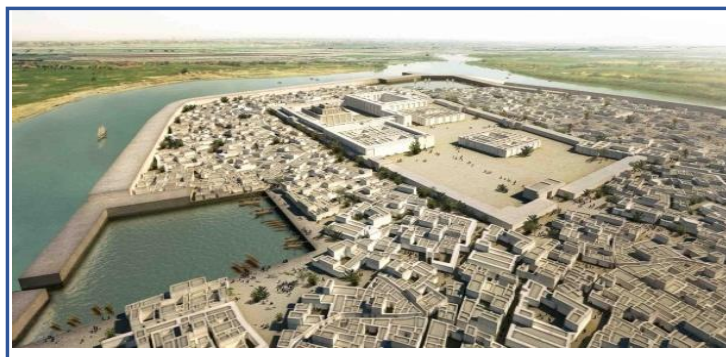

Figure- 5: The city of $\mathrm{Ur} 2^{\text {nd }}$ millennium BCE, $3 \mathrm{D}$ visualization, (website 5), illustrating the harbors of the city as nodes of concentration. Also the walls of the central Institution and the outer walls constitute defined city edges.

\subsection{Urban Life}

Life today may be faster paced, but the overall concerns have not really changed. We all need housing and food, work and leisure, family and friends [4]. The material embodiment that has been described above would not be sufficient in portraying Mesopotamian cities. Aspects of urban life and its daily issues fulfilled by residents of these cities should complement the whole view. The following would try to shed light on this side of the image.

\subsubsection{Social structure}

Scholars recognize the nuclear family as the basic social unit in the city. It comprises a married couple with their unmarried daughters and sons, and perhaps a widowed parent. The family could be enlarged by adoption or by incorporating in its structure outsiders named "brothers. A slave or more could also be owned by the private household and they may be articled to learn profitable crafts to increase their worth and consequently their master's wealth" [8], [12].

Professions, as well, constituted a strong social bond in the life of a Mesopotamian city dweller, and professional ties seemed to overlay ethnic identities and kin relations. Scholars differentiate mainly two categories of professions which enjoyed such bonds: first, there were Craftsmen who were highly

10 The German expedition to Uruk in 2002 confirmed that inhabitants of the city used water canals to move through the city and not big streets or something else.

http://www.rferl.org/content/article/1099592.html By Charles Recknagel May 03, 2002 specialized and there existed close associations for some crafts that had certain powers and accorded certain privileges to their members. And second, bureaucrats, priests and soldiers, who presented another category of professions. Like craftsmen, these as well were united by their affiliation to one public institution, the palace or the temple, and consequently they had their value in the social interactions [3].

\subsubsection{Administrative structure:}

A Mesopotamian king was the unique political power; he ruled on behalf of the gods and held responsibility for maintaining the gods' goodwill through rituals and by construction and maintenance of temples [13]. His main obligations to his citizens were to ensure that they are fed and protected from enemies. The king was the military leader in war and guaranteed the safety of his city through enforcing its fortifications, and the fertility of land through digging and maintaining irrigation canals. He was supported by his palatial organization, which comprised officials as administrators and warriors. They were responsible of arranging contacts between the king and citizenry.

Citizens had to fulfill their obedience to the king. They had to pay direct taxes, and perform services for the palace and its officials, to keep up roads and canals and to serve in the army. This relation between king and citizenry changed in scale overtime according to economic and political situation.

A Mesopotamian king was also the highest judicial authority in the state; he promulgated laws and price regulations to correct abuses. However, the city and each of its subdivisions or wards had their own local courts, which were referred to as "assemblies". The epic of Gilgammesh, in its second millennium version, mentions two types of these assemblies, one of the "elders" and the other of "of the battle experienced young men", but still, in the tale, the king made the last choice between the advices of the two councils [8],[14].

Temples were a separate political power. While they maintained the ideology of the "king chosen by the gods", they provided wealth and authority to priests and temple administrators even when opposing royal authority [3].

The role played by the palace and the temple in the solidarity of the city's society is enhanced through organizing public rituals and festivals. Although scholars stress that major temples were not congregational spaces; rather only those with ritual knowledge and preparation could be in the deity presence [13], their spacious geometrical courtyards, however, would have acted as open planned urban places for performing rituals and festivals, in which common people were spectators, and so they acted, in the words of McMahon, "as opportunities for transmission of messages of social cohesion, religious adherence or ideological conformity" [6].

In his daily life, the common Mesopotamian city dweller pursues two types of endeavors; in one hand there is the provision of his daily needs of food, water and the necessary or complementary artifacts for his 
uses. On the other, there is the work inside or outside the city which enables this urbanite to secure his needs. Another third aspect that complements human's life is not to be overlooked here, namely leisure. Beside these three daily concerns, there could be other adventitious activities like participating in or attending some meeting or assembly or processional ritual and so. Only the main two daily endeavors are highlighted below.

Urban residents had to acquire their food components $^{11}$ either from institutions, from fellow citizens, or from the farmers. In addition to institutional redistribution and mutual reciprocity, market transactions have been a third mode of food provision, all three modes were substantial to the economy, and none of the modes should be related with a particular sector of society [3].

Water was abundant close to lower Mesopotamian cities, where Rivers and canals were equally used for irrigation and transport. In Upper Mesopotamia, as well, Kings guaranteed that such water remained available to the city and its surrounding countryside. However, wells, as a second source for water, were most likely to be the choice for drinkable water for urbanites of both Assyria and Babylonia. They are less exposed to pollution factors than rivers and canals, and they are attested in texts from both Assyria and Babylonia. [3]

The securing of daily food and water required that a Mesopotamian urbanite be engaged in a constant profession. There was a wide variety of walks of life in Mesopotamian cities. Trade, industry, farming, building, and management are only examples that already include variant specialties. They were all interconnected in city life. It is out of the scope of this article to elucidate them all, and a spot of light is shed below on craftsmanship and on writing as special types of professions which provide the material evidences of the prosperity and heterogeneity of Mesopotamian urban professions.

Crafts grew and prosper in the early stages of the development of urban society, as they had the necessary means of raw materials and urban clientele, in addition to being exempted from the task of primary food production by the surplus of food available in cities.

Of the main crafts being distinguished in the Mesopotamian cities one could list: Potting, reed work, weaving, leather work, carpentry, stonecutting, metalwork and jewellery -making ${ }^{12}$. Highly skilled craftsmen were in demand by institutions as well as individuals. They might work in institutional workshops or have their own private ones. As

11 Food products were mostly from non- urban recourses. In addition to products grown in fields, orchards, and gardens, they also included those acquired through herding and food gathered through fishing, hunting. However, some types of food could have been produces in private households inside the city. Moreover, aquatic food of wide range of variety was provided from rivers and marshes.

12 Listed in [3] as the eight main city crafts. mentioned before, they had associations, with an overseer to manage their interactions with central institutions [3].

Writing may be considered the most urban-bound craft. It is recognized that it developed in Mesopotamia for the accounting purposes by temple bureaucrats and soon after palace administrators too.

These officials had to account periodically for the movements of goods, staples, and animals belonging to these institutions. Later on, writing expanded to other contexts such as literature and became significant to a substantial number of citizens.

In addition to public institutions of palace and temple, private urban entrepreneurs also required writing for their complex transactions. Moreover, many of the private scribes probably made their living by helping citizens with paperwork, as professional scribes still do today in the Middle East, as well as for prediction of future events, cures for illnesses, or rituals to avert evil. It is undoubted that Urban environment was the ideal context for all these intellectuals to work and prosper.

\section{The city as experienced by its resident:}

The mental image mediates in the interaction between bumans and their environment: The environment suggests distinctions and relations and the observer (...), selects and organizes and endows with meaning what it sees [7].

In the above sections, two aspects of the city were introduced; the five elements that define the Mesopotamian city's mental image, and the urban endeavors which might prompt the urbanite to a daily journey in his city. In This section a resident's journey is imagined in an unnamed Mesopotamian city. The description might seem more conform to Lower Mesopotamian cities such as Babylon, Ur, Uruk, etc., but it could also be compatible to main cities in upper Mesopotamia like the city of Assure, or even Khorsabad. The objective of this description is to portray the response and behavior of the resident towards the distinctions and relations suggested by his urban environment. This description is not to be taken as standard action but rather as a probable one, given to assist the drawing of the mental image of the city.

The daytrip might start as the resident leaves his house in the morning, for example, heading to the institutional center of the city, for work. He will pass through the net of pathways in his residential district, leading to the main path which must either finish by or pass by this destination with the main high temple as a landmark. When arriving, the buildings' scale is huge and massive, with its ample, highly geometrical urban spaces that are organized by symmetry and repetition of its architectural elements such as recesses and projections along with defined and limited entrances. (Figure 6)

Such aspects, must have promoted a behavior of docility by the visitor to the administrators of the place. The pace of his steps, the sound and type of talk and the way of looking and moving all these are carried out in a reserved and self-contained attitude. 


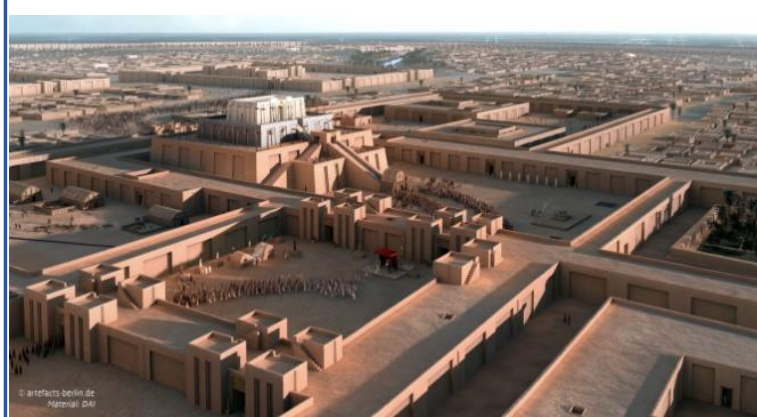

Figure- 6: The city of Uruk $3^{\text {rd }}$ millennium BCE, $3 \mathrm{D}$ visualization, (website 6 ), illustrating the architecture of the temple institution

But when the visiting resident moves out form the courtyard of the palace or temple, through the high gates of the precinct walls and starts walking in a main thoroughfare or to the city canal, then his movement would be more fluent and easy and he gets liberated from the feeling of submission. When he gets himself in a boat, heading to the city's market or inner harbor, he passes by the residential neighborhoods with their humble human scale and smooth organic fabric. There the scale and spaces are more intimate and people move under shades of date palms and other trees. (Figure 7)

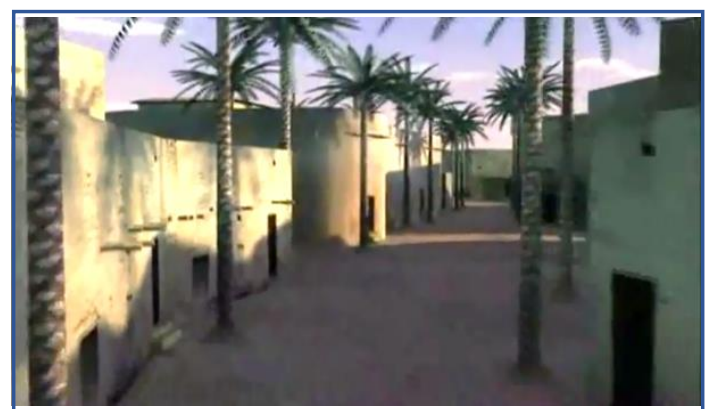

Figure 7: The city of Ur $2^{\text {nd }}$ millennium BCE, a shot from $3 \mathrm{D}$ visualization video, illustrating neighborhood's environment. Source (website 7)

Arriving at the harbor site, the Mesopotamian would engage in the more lively movement of people there, like traders and entrepreneurs from inside or outside the city, see Figure8. Some would arrive in boats through the water course, while others would be coming overland leading animals loaded with goods and materials countryside. Some would transfer merchandise to the warehouses, or meet the harbor administrator for an issue. From the harbor, one can see the high temple on top of the city's ziggurat as if announcing the gods' blessings over the city and its citizens from afar. Figure 9

The daily journey of the Mesopotamian resident could be finished by going back to his house or pass by some friends with whom to share company for some more time in a local tavern or so, and have his part of leisure for the day.

\section{Conclusion: Legibility of The Mesopotamian city}

A legible city would be one whose districts or landmarks or pathways are easily identifiable and are easily grouped into an over-all pattern [7].

In this article a representation of the Mesopotamian city was introduced through identifying its urban elements which constitute a clear and strong mental image to the resident Mesopotamian. Accordingly, the five elements listed by Kevin Lynch were matched as follows; the Ziggurat, temple, palace and gateways represented distinguishable landmarks. The network of alleys and streets along with the city canal, if present, represented the pathways. Nodes of the Mesopotamian city are found at the intersections or ends of paths. As for concentration nodes they are represented in the market or the harbor which are elements that witness active and easy movement and interaction of people, in addition to the grand courts in the central religious or palatial courtyards which occasionally host cult rituals. Districts of neighborhoods are recognized elements. While the city walls define the outer edge of the city, the canal and inner walls are recognized as inner edges that complement the image as they define boundaries between districts and beyond.

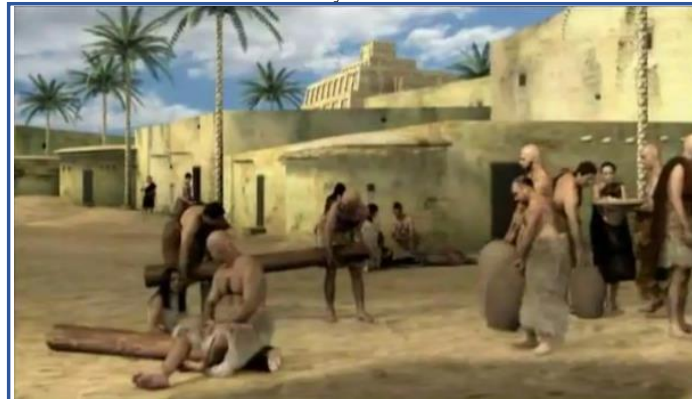

Figure 8: The city of Ur $2^{\text {nd }}$ millennium BCE, a shot from 3D visualization video, illustrating Sumerian People interacting in the market node. (website 7)

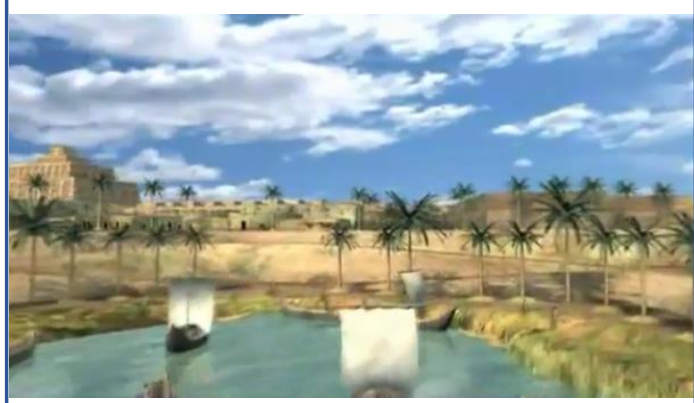

Figure 9:, A shot from 3D visualization video, illustrating the Harbor with the Ziggurat in the skyline of the city of Ur Source (website 7)

Each of the described element reflected distinctive characteristics that qualified it to be a recognized and legible part of the city. Yet, the image of a Mesopotamian city could not be appreciated just by categorization of elements. The described daily journey tried to portray the different environments within the city that these elements define. And the 
whole experience of this journey tried to help reintegration of those elements in a clear totality with which all parts can be organized into an overall coherent pattern, which the resident can feel and hold in his mind.

Thus, the article contributed in illuminating that Mesopotamian cities were legible cities inducing strong mental images to their inhabitants. This view corresponds strongly with the pride and recognition of their distinct self- qualities as urbanite cultured citizens, which the Mesopotamian expressed in textual inscriptions.

\section{References:}

[1] G. Filomena and J.A. Verstegen, "computational approach to "The Image of the City" in Cities, Edt. A. Manley,Volume 89,2019, pp 14-25.

[2] E. Stone, "The Spatial Organization of Mesopotamian Cities." in Aula Orientalis 1991, V. 9, pp235-242.

[3] M. Van de Meiroop. The Ancient Mesopotamian City, Oxford : Clarendon Press ; New York : Oxford University Press, 1997.

[4] B. W. Hafford, "Mesopotamian City Life" Expedition Magazine 60.1 (2018): Penn Museum, Web. 18 Apr 2021.[Online] Available:http://www.penn.museum/sites/exped ition $/ ? \mathrm{p}=25945$. [Accessed march 2021]

[5] A. McMahon, "Space, Sound and Light: Towards a Sensory Experience of Ancient Monumental Architecture" in American Journal of Archeology V.117, No.2, 2013.

[6] A. Mcmahon, "Mesopotamia" in The Oxford Handbook of Cities in World History, editor Peter Clark, Oxford University Press, 2013, pp38- 45.

[7] Lynch, Kevin, "The Image of the City", the MIT Press, 1960.

[8] A.L. Oppenheim, Ancient Mesopotamia: portrait of a dead civilization, The University of Chicago Press, 2nd ed. 1977.
[9] S.N. Kramer, Sumeria Mythology, parchment of 1944, published by: Aziloth Books, UK, 2013.

[10] T. Baqir, Muqadima Fi Adabil Iraq il Qadeem : An Introduction to the Literature of Ancient Iraq, P213.

[11] D.D. Luckenbill, The Annals of Sennacharib, Chicago, 1924.

[12] H. Saks, The Greatness of Babylon, translation by Amer Suleiman, Baghdad, 1979.

[13] G.Emberling, "Mesopotamian Cities and Urban Process, 3500-1600 BC", in The Cambridge World History, V.II, editor Norman Yoffee, Cambridge University Press, 2015, pp253- 278.

[14] H.J. Nissen, "Urbanisation and the Techniques of Communication" in The Cambridge World History, V.II, editor Norman Yoffee, Cambridge University Press, 2015, pp113- 130.

\section{Websites (sources of figures)}

1. https://www.mozaweb.com/en US/Extra3D scenes-

The city of Babylon 6th century B C-211433 (accessed in March 2021)

2. http://teachmiddleeast.lib.uchicago.edu/historica l-perspectives/empires-to-nation-states/beforeislam/images/empires-nations-before-islam14.jpg (accessed in June 2021)

3. http://mitchtestone.blogspot.com/2008/09/tapestry-ofpower-in-mesopotamian-city.html (accessed in June 2021)

4. https://archaeologyillustrated.com/collections/ur uk-southern-iraqthe-eanna-temple-complex3200bc/(accessed in October 2021)

5. https://i.imgur.com/zxNUGIl.jpg (accessed in March 2021)

6. https://www.afrikaiswoke.com/ancientsumer/(accessed in June 2021)

7. https://www.youtube.com/watch?v=j9G60jw0Nc0 (accessed in June 2021) 